\title{
Epidemiology of Bacterial Leaf Streak of Rice*
}

\author{
G. S. Sherhawat** and D. N. SRivastava***
}

G. S. SheKhAWAT** and D. N. SRIVASTAVA*** : イネ条斑細菌病の発生生態*

\begin{abstract}
Studies were conducted on the perpetuation and host range of the rice leaf streak pathogen Xanthomonas translucens f. sp. oryzae (Fang et al.) Pordesimo $(=X$. oryzicola Fang et al.) and the factors affecting the disease.

Seeds from a diseased crop when sown next season, developed diseased seedlings under field as well as laboratory conditions. The bacterium was isolated from these seedlings and its pathogenicity was confirmed. No diagnostic symptom attributable to bacterial infection was detected on such seeds, nor the bacterium could be isolated. The bacterium did not perpetuate in infected debris. Even in the leaves and bacterial beads stored under room conditions, the bacterium remained viable upto 90 and 75 days respectively. The bacterium did not infect any of the 30 grasses, 8 cereals and millets including maize and 4 species of Cyperus.

The young rice leaves were more susceptible to the disease, and became resistant with age. Two to three continuous days with high humidity (R.H. 83.0$89.5 \%$ ) or dew during morning hours were necessary for infection. The lesion enlargement was favoured by moderate temperatures $\left(26.1-30.5^{\circ} \mathrm{C}\right)$ and retarded at lower range (below $22.4^{\circ} \mathrm{C}$ ), irrespective of relative humidity.
\end{abstract}

(Received July 6, 1971)

\section{Introduction}

The bacterial leaf streak of rice incited by Xanthomonas translucens f. sp. oryzae (Fang et al.) Pordesimo $(=X$. oryzicola Fang et al. $)$ is prevalent in several Asian countries, viz., Philippines $^{10)}$, China ${ }^{2)}$, Thailand and Indonesia ${ }^{6}$, East Pakistan ${ }^{1)}$, West Malaysia ${ }^{15)}$ and India ${ }^{16)}$. Except for one report on seed transmission of the disease ${ }^{12}$, there is no other published work on its epidemiology. The earlier work relates to the evaluation of host resistance ${ }^{5,8,11,17)}$, and the nomenclature and phages of the pathogen ${ }^{4,6,7)}$.

In rainfed rice, the disease is known to cause an extensive damage. To develop effective control measures, a good understanding of epidemiology of the disease is essential. The present paper contains the results of investigations on perpetuation of the disease, host range of the pathogen, and the effect of weather conditions and age of the host on infection and disease development. A detailed paper on control aspect has been submitted for publication elsewhere ${ }^{13)}$.

* A part of the Ph. D. thesis of the senior author.

** Division of Mycology and Plant Pathology, Indian Agricultural Research Institute, New Delhi, India.

*** Indian Council of Agricultural Research, New Delhi, India. 


\section{Material and methods}

For isolation of the bacterium and its maintenance in culture, the medium employed was potato-sucrose-peptone-agar (PSPA)* with the following composition: peeled and diced potato $300 \mathrm{~g}$, peptone $2 \mathrm{~g}$, sucrose $20 \mathrm{~g}$, potassium phosphate $\left(\mathrm{KH}_{2} \mathrm{PO}_{4}\right) 0.2 \mathrm{~g}$, disodium phosphate $\left(\mathrm{Na}_{2} \mathrm{HPO}_{4} \cdot 12 \mathrm{H}_{2} \mathrm{O}\right) \quad 0.5 \mathrm{~g}$, calcium nitrate $\left[\mathrm{Ca}\left(\mathrm{NO}_{3}\right)_{2} \cdot 4 \mathrm{H}_{2} \mathrm{O}\right] 0.5 \mathrm{~g}$, potassium chloride ( $\mathrm{KCl}$ ) $0.05 \mathrm{~g}$, ferrous sulfate $\left(\mathrm{FeSO}_{4}\right) 0.05 \mathrm{~g}$, agar $20 \mathrm{~g}$, distilled water to make up the volume to 1 l.

Isolations were based on culturing of single colonies by streak plate method. Wherever necessary, the pathogenicity of the isolated bacterium was confirmed by inoculation of 7 weekold seedlings of rice variety IR 8 raised from healthy seeds. Unless stated otherwise, inoculations were made by the smearing of bacterial suspension on the leaf surface with a muslin cloth.

For the test of seed infection, 100 seeds of variety IR 8 from severely infected crop were subjected to visual examination for lesions on the husk. Microscopic examination was also tried for bacterial streaming from the pieces of husk and the sections of endosperm. Macerates of the seeds including the husk were also streaked on culture medium for isolation of the bacterium.

For field transmission of the disease, $100 \mathrm{~g}$ seeds of a mixture of rice varieties, harvested from an infected field in November, were sown by broadcasting in the first week of July in a plot of $3 \times 2 \mathrm{~m}$ at an isolated site where rice has never been cultivated. Seeds of the same varieties harvested from a healthy crop were simultaneously sown in another plot, same in size and well isolated from the previous one, to serve as control. These plots were given one application of ammonium sulfate at the rate of $180 \mathrm{~kg} / \mathrm{ha}$. Observations were made in both plots at weekly intervals after emergence, for visible symptom appearance. The weather during 45 days after sowing of seeds remained rainy and humid with a daily mean relative humidity range of 70.5-96.5 per cent and a temperature range of $26.1-30.1^{\circ} \mathrm{C}$. In plants showing symptoms of the disease, the identity of the bacterium was confirmed by isolation and pathogenicity tests.

A more critical examination of transmission of the disease through infected seeds was conducted under laboratory conditions on individual seed basis. A filter paper strip $(20 \times 1.4$ $\mathrm{cm}$ ) was inserted in a test tube $(1.5 \mathrm{~cm}$ in diameter) and folded twice near the mouth of the tube, so that one fold formed a kind of receptacle about $2 \mathrm{~cm}$ inside the mouth of the tube in which a seed was placed (Fig. 1). The tube was filled to the level of about $5 \mathrm{~cm}$ with sterile water to keep the entire strip moist. After germination, more water was added until the seed was covered. The tube was incubated at room temperature $\left(25.1-30.2^{\circ} \mathrm{C}\right)$ in a humid chamber. The seeds used in this test, consisted of a mixture of varieties, were harvested from a severely infected crop. Two hundred seeds were tested at a time and the test was repeated three times. The seedligs were observed 10 days after emergence concerning the appearance of streak lesions on the leaves, and the per cent of infection was recorded.

For studying perpetuation of the disease in infected debris, an streak infected rice crop was harvested in November. Half of the infected straw was buried $15 \mathrm{~cm}$ below the soil surface and the other half was spread on the surface. In the first week of July in next season,

* Suggested by Dr. T. Mizukami, National Institute of Agricultural Sciences, Tokyo, Japan, during his visits to our laboratory. 
the plot was ploughed and sown the healthy seeds of rice variety IR 8 . Ammonium sulfate was applied at the rate of $180 \mathrm{~kg} / \mathrm{ha}$. Observations were recorded on the appearance of disease symptoms until maturity of the crop. The weather during 45 days after sowing remained rainy and humid with a daily mean relative humidity ranging from $70.5-96.5$ per cent and a temperature of $26.1-30.1^{\circ} \mathrm{C}$.

For the determination of the duration of viability of the pathogen in infected leaves and bacterial beads on the leaf surface under laboratory conditions, leaves showing isolated streaks with abundant bacterial beads were stored under room conditions. The viability of the bacterium was tested fortnightly by inoculating suspensions of the beads and leaf macerates on rice seedlings and also by attempting direct isolation.

To study the relationship of age of the rice plant to infection and disease development, the seeds of variety IR 8 were sown in pots at 15 days' intervals, so as to obtain the plants of different ages at the same time for

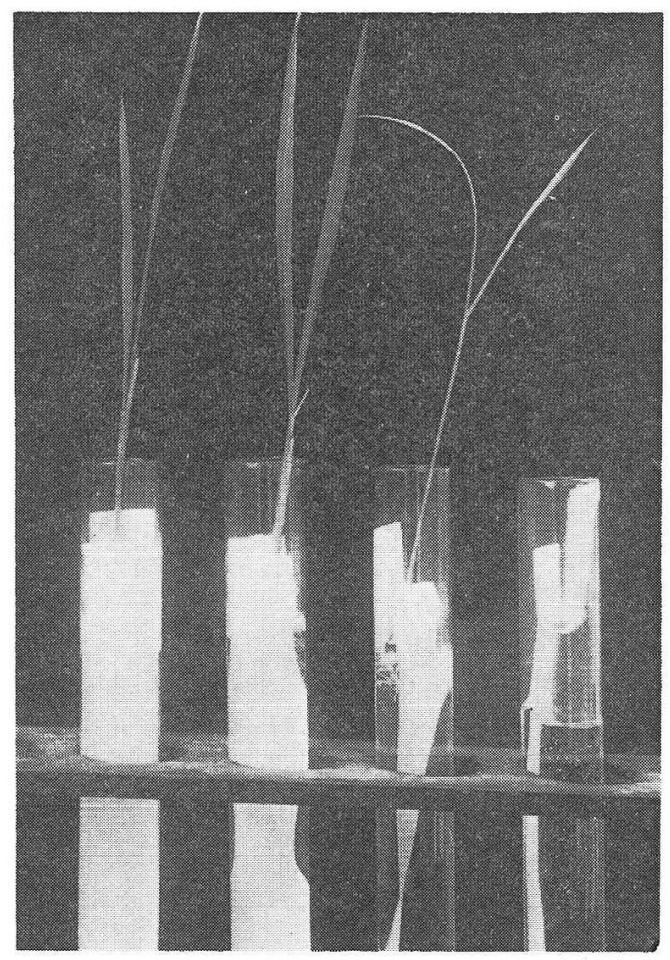

Fig. 1. Method employed for testing seed transmission of bacterial leaf streak of rice in single seed. inoculation. In each case, leaves of 10 plants were inoculated. The criteria used for the evaluation of the relative susceptibility of different ages of the host were; (i) incubation period, (ii) number of leaves infected in a tiller, (iii) average length of lesion on 20 leaves selected randomly from each treatment and (iv) the extent of bacterial exudate on the infected leaves.

Since the flag leaf plays a vital role in kernel formation, its susceptibility was also tested at different stages of development, i. e. immediately after its emergence, after its full growth, at the time of panicle emergence and at the time of initiation of kernel formation. These 4 developmental stages could be obtained in the same stool for inoculation at one time. The flag leaves at each stage were inoculated by smear method. Two varieties, IR 8 and Taichung Native 1, were used in this experiment. The criteria used to determine relative susceptibility at the 4 stages were; (i) incubation period, (ii) average lesion length and (iii) the extent of bacterial exudate on leaf surface.

The influence of fluctuations is weather conditions on incubation period and lesion enlargement was studied under natural conditions from June to December during the years 1968 and 1969. Twenty potted plants of variety IR 8 (45-60 days old) were inoculated at 15-day intervals and kept in the open air. The number or days taken for symptom appearance and the lesion length at the 10th day after symptom appearance were recorded. The lesion length was the average of measurements of 200 isolated lesions on 10 randomly selected leaves. The weather data were obtained from the Institute's observatory. 


\section{Results}

\section{Perpetuation of the disease}

Seed infection Visual examination of seeds did not show any lesion or discolouration suggestive of bacterial infection. When the pieces of seed husk and the sections of endosperm were mounted on water and examined microscopically, none of the 100 seeds examined showed bacterial streaming. No colony of Xanthomonas could be observed in PSPA plates streaked with suspension of macerates of 100 seeds, although colonies of several saprophytic bacteria were encountered.

Seed transmission of the disease In the plot sown with seeds from infected crop, visible symptoms typical of early stages of streak were noticed on the leaves of 10 per cent of the plants in the $4 \mathrm{th}$ week. In later stages all the plants became infected and showed various stages of the disease. The control remained free from infection till the end of the season.

When the seeds from diseased crop were germinated individually in test tubes, 7 per cent of the resultant seedlings developed water-soaked minute flecks on first and second leaves. The lesions enlarged to $2 \mathrm{~mm}$ in the next few days and turned brownish in colour.

Preparation of the pathogen in debris In the prot with infected debris, the plants remained free of streak symptoms till the end of season. In infected leaves and bacterial beads on the leaf surface stored under room conditions, the bacterium remained viable only up to 90 and 75 days, respectively.

\section{Host range}

Thirty grasses, 8 cereals and millets including maize and 4 species of Cyperus were tested on the host range of the bacterium. These plants included, Acrachne racemosa, Brachiaria dystachya, B. decumbens, B. mutica, B. ramosa, Cenchrus ciliaris, Chloris gayana, Cynodon dactylon, Dicanthium annulatum, Digitaria adscendens, D. decumbens, Echinochloa colonum, Eleusine coracana, E. indica, Eragrostis tenella, Eurochloa prosera, Panicum miliaceum, P. maximum, Paspalidium flavidum, Paspalum conjugatum, P. dilatatum, P. scrobiculatum, Pennisetum pedicillatum, P. purpureum, P. typhoides, Saccharum officinarum, S. spontaneum, Setaria italica, S. verticillata, Sorghum halepense, S. vulgare, Themeda termula, Urochloa stolonifer, U. prosora, Zea mays, Cyperus compressus, C. iria, C. rotundus, C. difformis, Triticum vulgare (var. Sonalika), Hordeum vulgare (var. R. S. 6) and Avena sativa (var. Kent). Twenty leaves of each plant were inoculated. Observations on disease symptoms and bacterial streaming from inoculated portions of the leaves were done until 15th day.

None of the plants developed symptoms of the disease, nor showed bacterial streaming from leaf pieces examined from the site of inoculation under microscope.

\section{Relationship of age of the host to infection and disease development}

It can be seen from Table 1, that the host remained highly susceptible to the disease up to 60 days. All the leaves became infected within $60 \mathrm{hr}$, the streak lesions enlarged rapidly and were coated with numerous beads of bacterium. At 75 days and thereafter, all the leaves except the top two leaves, one of which was the flag leaf, became resistant to infection. Even the top two leaves became resistant with age, particularly at maturity the resistance was fairly marked, leading to the significant increase in the incubation period and reduction in the lesion length and the amount of bacterial beads.

\section{Relationship of age of the flag leaf to infection and disease development}

In the preceding experiment, no clear difference in the susceptibility of the flag leaf at 
Table 1. Susceptibility of rice plant of different ages to Xanthomonas translucens $\mathrm{f}$. sp. oryzae

\begin{tabular}{|c|c|c|c|c|}
\hline $\begin{array}{l}\text { Age of } \\
\text { plants } \\
\text { (days) }\end{array}$ & $\begin{array}{l}\text { Incubation } \\
\text { period(hr) }\end{array}$ & $\begin{array}{l}\text { Leaves infected } \\
\text { in the tillers }\end{array}$ & $\begin{array}{c}\text { Length of } \\
\text { streaks } \\
(\mathrm{mm})\end{array}$ & $\begin{array}{c}\text { Bacterial } \\
\text { beads }\end{array}$ \\
\hline 15 & 60 & All & 7.5 & Abundant \\
\hline 30 & 60 & All & 15.3 & Adundant \\
\hline 45 & 60 & Al1 & 15.4 & Abundant \\
\hline 60 & 60 & All & 15.2 & Abundant \\
\hline 75 & $60-84$ & $\begin{array}{c}\text { Only top two } \\
\text { (young) }\end{array}$ & 13.0 & Abundant \\
\hline 90 & $84-104$ & $\begin{array}{c}\text { Only top two } \\
\text { (nearing maturity) }\end{array}$ & 12.5 & Moderate \\
\hline 105 & $108-120$ & $\begin{array}{l}\text { Only top two } \\
\text { (mature) }\end{array}$ & $\begin{array}{l}\text { Pin-heads } \\
\text { to } 5.0\end{array}$ & Scanty \\
\hline
\end{tabular}

different growth stages was obtained. Therefore, flag leaves at 4 growth stages were tested separately. The data obtained in both varieties IR 8 and Taichung Native 1, were similar and are preseted in Table 2.

The results show that the susceptibility of the flag leaf decreased with age. At the stage of kernel formation, the lesions were tiny and without any bacterial beads.

Table 2. Susceptibility of flag leaf of rice at different stages of growth to Xanthomonas translucens f. sp. oryzae

\begin{tabular}{lccl}
\hline $\begin{array}{c}\text { Growth stage } \\
\text { of flag leaf }\end{array}$ & $\begin{array}{c}\text { Incubation } \\
\text { period(hr) }\end{array}$ & $\begin{array}{c}\text { Length of } \\
\text { streak(mm) }\end{array}$ & $\begin{array}{c}\text { Bacterial } \\
\text { beads }\end{array}$ \\
\hline $\begin{array}{l}\text { Newly emerged } \\
\text { Fully developed }\end{array}$ & 60 & 13.5 & $\begin{array}{l}\text { Abundant } \\
\text { Moderate }\end{array}$ \\
$\begin{array}{l}\text { Immediately after } \\
\text { panicle emergence }\end{array}$ & $84-120$ & 7.5 & 3.0 \\
$\begin{array}{l}\text { At initiation of } \\
\text { grain formation }\end{array}$ & $120-132$ & 1.0 & Nil \\
\hline
\end{tabular}

\section{Relationship of environmental conditions to disease development}

The 2 years' data on the effects of environmental conditions on the incubation period are presented in Fig. 2, and those on the lesion length are in Fig. 3.

From Fig. 2, it is seen that the incubation period was inversely related to the relative humidity, but the temperature had little effect. In inoculation during June to September, whenever incubation period was unusually long, the weather during the period was dry except for the last 2-3 days which were cloudy and humid (R.H. 74-94\%), accompanied by dew during the early morning. During above period when the relative humidity, irrespecitive of temperature, was less than 50 per cent for 15 days after inoculation, infection did not occur. In the month of October and November, mean relative humidity was lower (41.0-59.0\%), but infection occurred though the incubation period was lengthened. This was probably due to the nights during the period remained cool and humid with dew formation, and the leaves remained covered with dew drops during early morning, and at times even for 1-2 hr after sunrise. Thus it is clear that 2-3 continuous humid days or dew during morning was necessary for infection. 


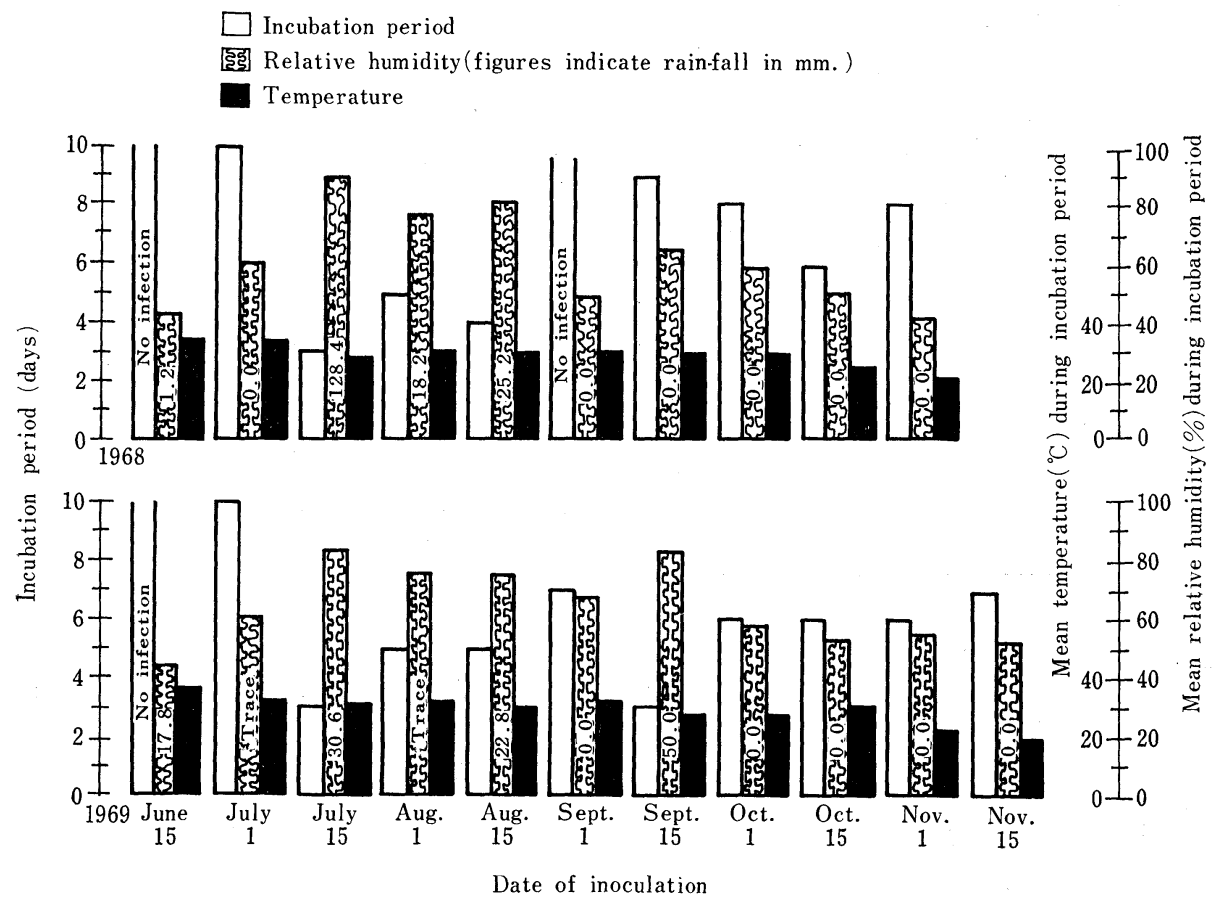

Fig. 2. Effect of temperature, humididy and rainfall on incubation period of bacterial leaf streak of rice.

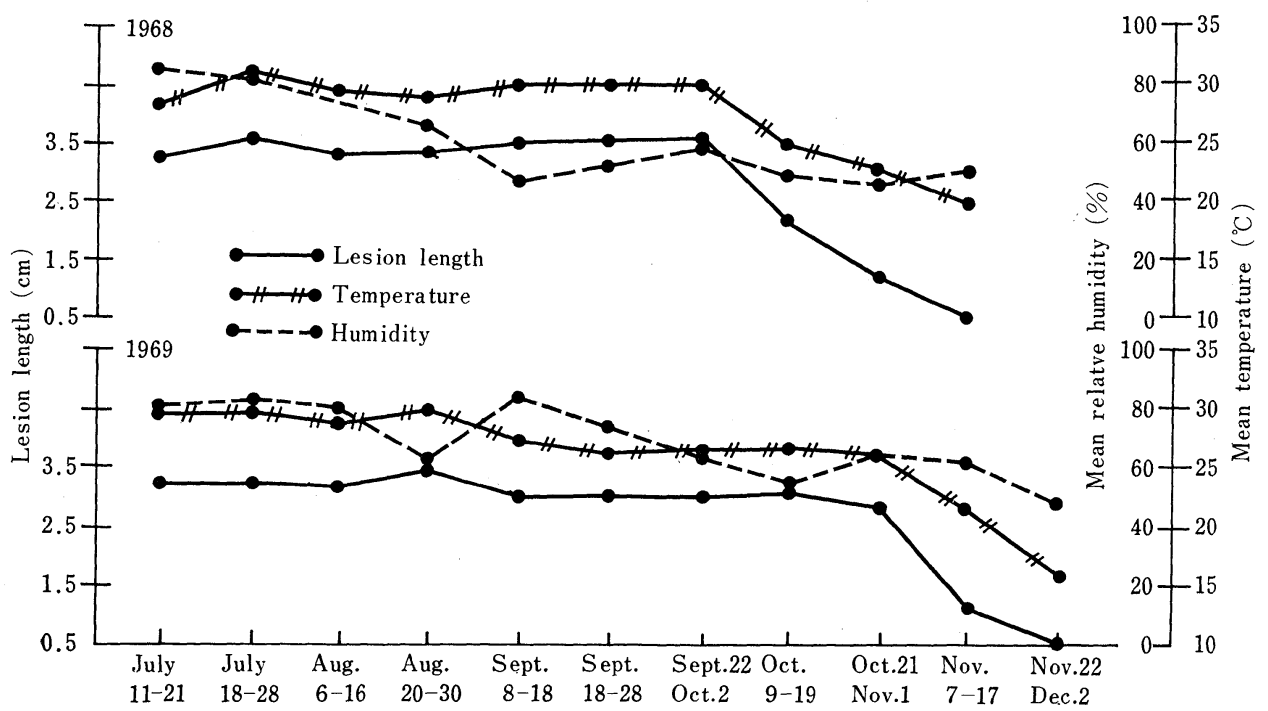

Fig. 3. Effect of temperature and humidity on lesion enlargement in bacterial leaf streak of rice.

The data presented in Fig. 3, show that in general, the lesion length decreased with the decrease in mean temperature, irrespective of the relative humidity. During July to September when the mean temperature was relatively constant $\left(26.1-30.5^{\circ} \mathrm{C}\right)$, despite the fluctuations in the mean relative humidity (56.4-85.0\%), the average lesion length was $3.0-3.5 \mathrm{~cm}$. During 
October and November where the temperature was below $22.4^{\circ} \mathrm{C}$, the lesion length was significantly reduced.

\section{Discussion}

The results show that the pathogen can survive in the infected seed from one season to another, but not in the infected debris. The disease is readily transmitted from infected seed to the plants under favourable conditions. No evidence of any cultivated or wild plant acting as host of the pathogen was obtained. Hence, seeds from diseased crop constitute a potential source of epidemics, especially in the single-cropped areas.

From naturally infected seed, it was difficult to discern any visible or microscopic signs of presence of the bacterium in any part of the seed, nor it was possible to isolate the bacterium directly from the seed. However, in another paper ${ }^{14)}$ the authors have demonstrated the infection in floral parts and seed by the artificial inoculation to the panicles at flowering, pre-milk and post-milk stages. This was probably due to very rigorous conditions of infection. Considering the fact that the host plant usually becomes resistant to the pathogen at maturity time, natural infection of the seeds may not occur to an extent demonstrable by visual or microscopic means.

On the basis of the above mentioned finding, it becomes imperative that the countries where the disease is not reported to occur should pay precaution in introducing seeds from the countries where the disease is prevalent. If it becomes absolutely necessary to introduce seeds from such countries, the seed lot should be treated according to the method described by the authors ${ }^{13)}$ and be tested at least for one generation to obtain disease free seeds.

For infection, atmospheric humidity was the critical factor but not the temperature. Continuous high humidity for 2-3 days following inoculation was necessary for rapid infection. However, the temperature was more important than relative humidity for enlargement of the lesion; the optimum temperature seemed to lie between 26.0 and $30.0^{\circ} \mathrm{C}$.

The age of plant and that of the individual leaves played a determining role in infection and disease development. The young leaves were susceptible, but became resistant with age. Senescent leaves failed to take up infection. These findings are of significance in the epidemiology of the disease. In nature the apparent severe disease at all ages of the leaves, even beyond the booting stage, would imply that some continuous favourable conditions for successive infection of young leaves might be existed. This process of successive infection may discontinue during dry spells and thus limit the disease spread. This explains why the disease has not assumed as destructive as the bacterial leaf blight of rice, despite of the presence of abundant viable and dispersible inoculum on both surfaces of the diseased leaves. A short dry spell may lead to a disruption and discontinuity of infection of the young leaves from the inoculum on older ones and thus may break the disease cycle.

\section{Acknowledgements}

The authors are grateful to Dr. M.S. Swaminathan, Director, and to Dr. S. P. Raychaudhuri, Head of the Division of Mycology and Plant Pathology, for their kind preparation of facilities for this work. Thanks are also due to Dr. Y.P. Rao, Plant Bacteriologist, and to Mr. S. K. Mohan, Assistant Plant Bacteriologist, for their help in various ways. The senior author 
expresses his gratitude to the Indian Council of Agricultural Research for the award of a Senior Research Fellowsnip for this study.

\section{Literature cited}

1. Alim, A. (1967). Trop. Agr. Res. Ser. No. 1: 199-208. Agr. Forest. Fish. Res. Council, MAF, Japan.

2. Fang, C. T., Ren, H.C., Chen, T. Y., Chu, Y.K., Faan, H. C. and Wu, S. C. (1957). Acta Phytopath. Sinica 3: 99-124.

3. Faan, H. C. and Wu, S. C. (1965). Acta Phytophylac. Sinica 4: 1-6.

4. Goto, M. (1964). Rep. Fac. Agr. Shizuoka Univ. 14: 3-10.

5. Goto, M. (1965a). Philip. Agr. 48: 329-338.

6. Goto, M. (1965b). Ann. Phytopath. Soc. Japan 30: 253-257.

7. Goto, M., and Okabe, N. (1965). Rep. Fac. Agr. Shizuoka Univ. 15: 39-44.

8. Ou, S. H. and Jennings, P. R. (1969). Ann. Rev. Phytopath. 7: 383-410.

9. Pordesimo, A. N. (1958). Philip. Agr. 42: 115-128.

10. Reinking, O. A. (1918). Philip. J. Sci. Sec. A. 13: 225-226.

11. Row, K.V.S.R.K., Devadath, S., Dath, A.P. and Padmanabhan, S. Y. (1968). Riso 16: 327-336.

12. Shekhawat, G. S., Srivastava, D. N. and Rao, Y. P. (1969). P1. Dis. Reptr. 53: 115-116.

13. Shekhawat, G.S. and Srivastava, D. N. (1971a). Indian J. Agr. Sci. (in press)

14. Shekhawat, G. S. and Srivastava, D. N. (1911b). Ann. Phytopath. Soc. Japan (in press)

15. Singh, K. G. (1969). FAO P1. Prot. Bull. 17: 64-66.

16. Srivastava, D. N., Rao, Y. P., Durgapal, J. C. and Jindal, J. K. (1967). P1. Dis. Reptr. 51: 928929.

17. Anonymous (1967). Ann. Rep. Inter. Rice. Res. Inst. Philippines. 1966: 94-97.

\section{和文摘要}

\section{イネ条斑細菌病の発生生態}

\section{G. S. Shekhawat and D. N. SRivastava}

イネ条斑細菌病菌，Xanthomonas translucens f. sp. oryzae (Fang et al.) Pordesimo (=X. oryzicola Fang et al.) の生存, 寄主範囲和よび発病に及ぼす諸要因について研究した。

発病圃場からの種子は次の作期にまくと, 圃場条件でも室内条件でも発病苗を生じた。これらの苗からは 細菌が分離され，その病原性が確かめられた。しかし，このよらな種子では細菌感染を示す病徵が見られ ず, 病原細菌も分離されなかった。病原細菌は病植物の遺体では永存せず, 室内で保存した葉および細菌塊 中でもそれぞれ90日执よび 75 日までしか生存しない。この病原細菌は 30 種のイネ科植物, トウモロコシ を含む 8 種の禾穀類, 4 種の Cyperus 属植物を侵さない。

若いイネの葉は本病に感受性高く, 古くなるに従って抵抗性になる。感染には高湿度（関係湿度 83.089.5\%）または早朝の結露が 2-3 日間続くことが必要である。病斑の拡大は湿度に関係なく中程度の温度 $\left(26.1-30.5^{\circ} \mathrm{C}\right)$ で促進され，低い温度 $\left(22.4^{\circ} \mathrm{C}\right.$ 以下) では抑制される。 